\title{
Free Energy Landscape Approach to Glass Transition
}

Takashi Odagaki

Department of Physics, Kyushu University

\section{0}

\section{0}

\begin{abstract}
A free energy landscape (FEL) picture of the glass transition is presented, which provides a unified understanding of glass transition singularities. This view is a straight forward generalization of the Landau theory of phase transitions with atomic configuration in place of the order parameter. Exploiting the density functional theory, we show that the FEL can really be calculated and argue that there are two kinds of cooperatively rearranging regions: One is the region defined by the difference between two adjacent basins, which could be called a simultaneously rearranging region, and the other is the atoms involved in the excited state between two adjacent basins. We obtain the FEL for a relaxation process which is characterized by a string motion and determine the size of the cooperatively rearranging region.

Keywords: Glass transition, Landau theory, Free energy landscape, Density functional theory, Cooperatively and simultaneously rearranging regions
\end{abstract}

1. はじめに

「エネルギーランドスケープ, 自由なのか位置 なのか, それが問題だ」というシェイクスピア流 の問は，ガラス関係の最近の国際会議で論争の焦 点となってきた. ガラス転移の研究は, この 20 年 程の間に格段に進歩し，この基本的な問題に対し ても最近ようやく答えが見えつつある.

非平衡状態で観測されるガラス転移をどのよ うな現象と考えるかについて，大きく言って三つ の考え方が提案されてきた. Götze [1] によって提 案されたモード結合理論は，ガラス化を過冷却液 体の固化と考え，液体の密度摇らぎが減衰しなく なる点を理想的なガラス転移と捉えるものであ る. 実際, 記憶効果の増大により, そのような転 移が起こることが示され，実験と詳細に比較され たが, 理論から導かれる転移温度は，実際のガラ ス転移温度より高いと結論されるようになった。 モード結合理論は, 液体のダイナミックスを平均 場的描像で扱ったものであり，個々の原子のジャ ンプ運動などが主要な働きをする系には適用で きないことを示している。

一方，Parisi らは，理想的なガラス転移を配置 エントロピーが消滅する点（すなわち Kauzmann 温度）と考え，レプリカ法を用いて過冷却液体・ ガラス状態の配置エントロピーを計算し, 転移点 を求めた[2]. この理論は，実験で観測される転移 点で比熱が急激に減少する事実を定性的に説明 できるが, 転移点の冷却速度依存性などの特徴は 説明できない，また Kauzmann 温度は実際のガラ
ス転移温度より低いことが知られている。

筆者らは，ガラス転移点の近傍の過冷却液体で, 原子の速い運動と遅い運動が分離することに着 目し，ガラス転移を構造緩和の待ち時間が発散す る点と捉える全く別の考え方を提出した[3]. この 描像によるガラス化は，速い運動の平均から定ま る原子構造の緩和の遅延化に対応する. ガラス転 移を，動的にはガウシアンーノンガウシアン転移， 熱力学的にはアニールドークエンチド転移とし て統一的に理解する現象論的枠組みを与えるこ の描像は，トラップモデルと呼ばれている[4,5]. このモデルに基づき，ガラス転移温度以下で比熱 が急激に減少することやガラス転移温度が泠却 速度に依存する（冷却速度が遅いと低温側にずれ る）ことが示されている.

この理論によれば, 熱力学的に定義される Kauzmann 温度 $T_{\mathrm{K}}$ と, 粘性係数の発散から定義さ れる Vogel-Fulcher 温度 $T_{0}$ が等しいこと，またガ ラス転移温度 $T_{\mathrm{g}}$ およびさらに高温側で見られる クロスオーバー温度 $T_{\mathrm{X}}$ と $T_{0}$ との間に $T_{\mathrm{X}} / T_{\mathrm{g}}=2-$ $T_{0} / T_{\mathrm{g}}$ という関係が存在することが示される．この 関係式は，実験データとよい一致を示すことが知 られている[6].

トラップモデルにより，現象論的にはガラス転 移のほとんど全ての特徴を説明することができ る. 現在, ガラス転移の実体論の構築のために, 自由エネルギーランドスケープ描像に基づいて, トラップモデルの微視的な基礎付けを行う努力 が行われている。 
本稿では，自由エネルギーランドスケープとは 何か，またそれから何が期待できるのかを簡単に 解説する.

\section{2. 自由エネルギーランドスケープ}

まず，全ての原子をある配置 $\left\{\mathbf{R}_{i}\right\}$ に固定し，そ の構造のトポロジーを変えない範囲で各原子を 変位させる.この空間におけるボルツマン因子の 積分によって部分（配位）分配関数を定義する：

$$
\begin{aligned}
& Z\left(T, V, N,\left\{\mathbf{R}_{i}\right\}\right)= \\
& \int \cdots \int \exp \left[-\beta \Phi\left(\left\{\mathbf{r}_{i}\right\}\right)\right] \Delta\left(\left\{\mathbf{r}_{i}-\mathbf{R}_{i}\right\}\right) d\left\{\mathbf{r}_{i}\right\}
\end{aligned}
$$

ここで, $\beta=1 / k_{B} T,\left\{\mathbf{r}_{i}\right\}$ は原子の位置ベクトル, また $\Phi\left(\left\{\mathbf{r}_{i}\right\}\right)$ は位置エネルギーであり, ゲート関数 $\Delta\left(\left\{\mathbf{r}_{i}-\mathbf{R}_{i}\right\}\right)$ は, 各原子の積分領域を規定するもの である. 部分分配関数から自由エネルギーを $\left\{\mathbf{R}_{i}\right\}$ の関数として決めることができる：

$$
\begin{aligned}
& F\left(T, V, N,\left\{\mathbf{R}_{i}\right\}\right)=-k_{B} T \ln Z\left(T, V, N,\left\{\mathbf{R}_{i}\right\}\right) \\
& +K . E .
\end{aligned}
$$

K.E. は運動エネルギーの寄与を表す。この $F\left(T, V, N,\left\{\mathbf{R}_{i}\right\}\right)$ を自由エネルギーランドスケープ の定義とする．実際の計算においては，ゲート関 数をガウシアン関数で近似することができる：

$$
\Delta\left(\left\{\mathbf{r}_{i}-\mathbf{R}_{i}\right\}\right)=\sum_{i} A \exp \left[-\alpha\left(\mathbf{r}_{i}-\mathbf{R}_{i}\right)^{2}\right]
$$

ここで，Aは規格化定数である.ランドスケープ を定義する空間は，仮想的な外場によって固定さ れた平均原子位置であることは重要な点である. これは，ランダウの相転移理論において，熱力学 ポテンシャルを秩序変数で展開するとき, 秩序変 数がある值をもつ状態は仮想外場によって作ら れるものであるということと同じ考え方である.

自由エネルギーランドスケープの定義から，協 調緩和領域[7]について, 重要な結論が導かれる. 自由エネルギーランドスケープには，多くの局所 的な最小点 (ベイスンと呼ぶ) が存在する. 隣り 合ったベイスンの原子配置の差は，通常数個の原 子の位置である. この数個の原子は, 系がこれら のベイスン間で構造緩和するときに同時に変位 する原子であり，これらの原子は同時緩和領域

(Simultaneously rearranging region: SRR) と呼ぶこ とができる.一方，二つのベイスン間の緩和は， 途中の峠点近くの励起状態を経て起こる.この状 態は，SRRの原子だけでなく，協調して変位する さらに多くの原子が必要である。この領域が,

Adam and Gibbs[7] によって導入された協調緩和 領域 (Cooperatively rearranging region: CRR)，すな わち構造緩和に必要となるエントロピーを協調 的に供給できる領域と考えてよい，言い換えると， CRR 程度の原子集団の自由エネルギーランドス ケープにより，構造緩和の素過程が決まる。すな わち，構造緩和の素過程の統計情報を得るために は，アボガドロ数程度ではなく $\mathrm{CRR}$ 程度の原子
座標で張られる空間の自由エネルギーランドス ケープを調べればよいことになる。

自由エネルギーランドスケープと位置エネル ギーランドスケープの決定的な違いの一つは，前 者が温度に依存するのに対して, 後者は温度には 依存しないことである.自由エネルギーランドス ケープの期待される振る舞いを Fig.1 に模式的に 示す.

$T>T_{C}$

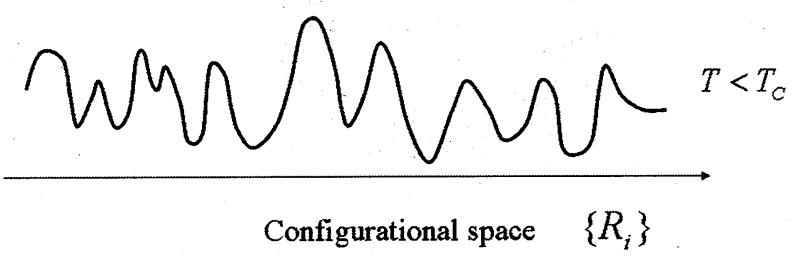

Fig.1 Schematic illustration of the free energy. landscape. The flat landscape at higher temperatures becomes a ragged one at lower temperatures.

高温では平坦であった自由エネルギーは，低温 になると多数のべイスンをもつ構造となり, 緩和 過程はベイスン内の速い緩和とベイスン間の遅 い緩和に分離する. 温度が下がると, 各ベイスン の深さが増し, 構造緩和の遅延化が起こる. トラ ップモデルによれば, 遅い緩和の平均待ち時間が 観測時間より長くなる点がガラス転移点である. さらに低温で, 構造緩和が停止する温度が存在し, その温度が Kauzmann 温度となる。

次節では，このような自由エネルギーランドス ケープが実際に求められることを示す。

\section{3. 密度汎関数理論}

密度汎関数理論では, 熱力学ポテンシャルを密 度場の関数として表す.グランドポテンシャルの 最も単純な表現が, Ramakrishnan and Yussouffによ って与えられている[8]:

$$
\begin{aligned}
& \beta \Omega[\rho(\mathbf{r})]-\beta \Omega\left[\rho_{l}\right]= \\
& \int \rho(\mathbf{r}) \log \left[\rho(\mathbf{r}) / \rho_{l}\right] d \mathbf{r}-\int\left[\rho(\mathbf{r})-\rho_{l}\right] d \mathbf{r}- \\
& \frac{1}{2} \iint C\left(\left|\mathbf{r}_{1}-\mathbf{r}_{2}\right|\right)\left[\rho\left(\mathbf{r}_{1}\right)-\rho_{l}\right]\left[\rho\left(\mathbf{r}_{2}\right)-\rho_{l}\right] d \mathbf{r}_{1} d \mathbf{r}_{2}
\end{aligned}
$$

ここで $\rho_{l}$ は一様な液体の密度, $C\left(\left|\mathbf{r}_{1}-\mathbf{r}_{2}\right|\right)$ は直 接相関関数である. 密度場としてガウス関数 (3) を採用すると, グランドポテンシャルは原子の位 置 $\left\{\mathbf{R}_{i}\right\}$ の関数となる.これを, 前節で導入した自 由エネルギーランドスケープと見なすことがで きる.

われわれは，剛体球系について (4) 式を用いて 実際に自由エネルギーランドスケープを計算し た[9]. 自由エネルギーランドスケープを 1 次元的 に表現するために，ランダムな粒子の配置を用意 
し, Fig.2 に示すように周囲の粒子を固定したセル を考える．まず，セル内の粒子位置をグランドポ テンシャルが最小となるように最適化する. 次に, セル内の 1 個の粒子を強制的に変位させ，他の粒 子の位置を最適化した状態の自由エネルギーを 求める. 直接相関関数には Percus-Yevick の式を用 いる.

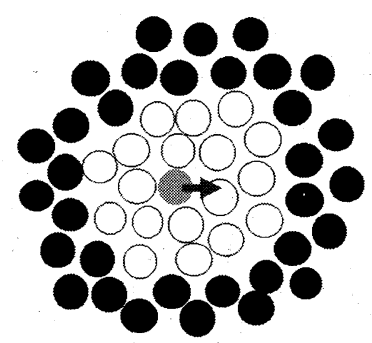

Fig.2 The free energy is calculated for given positions of a selected atom. Positions of other atoms in the confined cell are relaxed so that the grand potential is minimized.

Fig.3 は，過冷却液体に対応する密度で，セル内 の粒子数が 10 個の場合の自由エネルギーを，強 制的に変位させた粒子の変位の関数として示し たものである[9]. 粒子直径の 7 割ほど変位したと ころで, 自由エネルギーの大きな変化があり, 構 造緩和が起こる．実際，横軸上の各点においてセ ル内の全粒子の配置を再度緩和させたときに，こ の点の両側で異なった構造に緩和することが確 かめられるので，その点で別のベイスンに移るこ とが分かる。

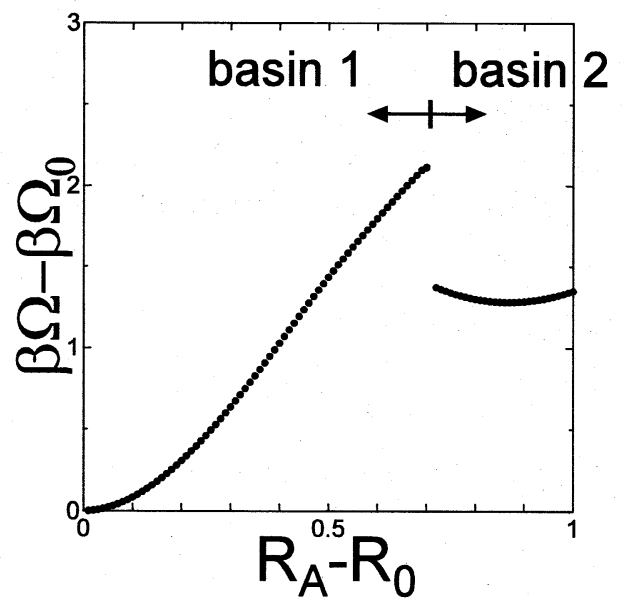

Fig.3 The free energy landscape as a function of the displacement of a selected sphere. The ten spheres confined in the cell undergo a structural transition in this process.

Fig.3 の過程で見られたベイスン間の遷移を詳 細に調べた[9]. 位置をコントロールされる粒子お よびセル内の他の全ての粒子の，最適化された位

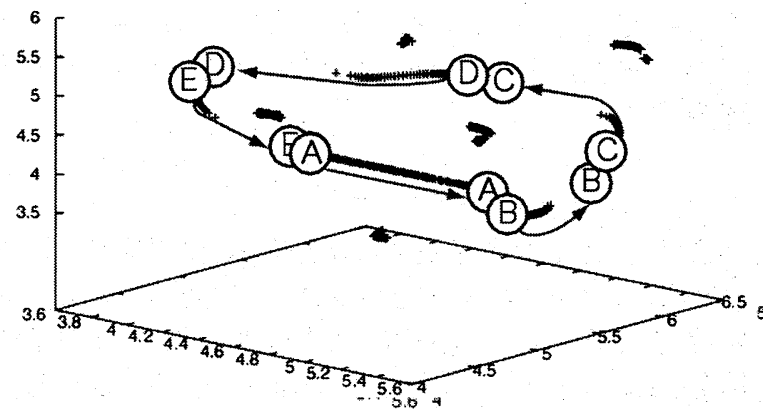

Fig.4 Five spheres change their positions as shown by arrows, while other five spheres keep their relative positions. $A$ is the sphere forced to displace

置を 3 次元的に図示したのが Fig.4 である. 強制 的に変位をさせた粒子を含めて 5 個の粒子が粒子 間距離程度の大きな変位をし, しかも連なって変 位をしている。この構造変化は，シミュレーショ ンで観測されている連結運動(String motion) に対 応寸るものである. 他の 5 個の粒子はほとんど変 位をしていないので, この構造緩和の SRR は. 5 個である.

セルの大きさを変化させることにより, CRRの 大きさを推定することができる．すなわち，セル 内の粒子数を減少させると, 粒子を変位させても 構造緩和が起こらなくなるサイズがある. CRR の 大きさは密度の増加とともに増加することが示 される[9].

4. 中性子でガラス転移を見る

4.1. これまでの主な研究

ガラス転移の実験による研究は，この 20 年ほ どの間に極めて活発に行われきた. ガラス転移の 動的性質に関する多くの知見は中性子を用いた 実験により得られたものである。その切っ掛けと なった害験は, Mezei によって開発された中性子 スピンエコーによる中間散乱関数の直接測定で ある $[10]$. この実験により, 過冷却液体で遅い緩 和が見られること，またその緩和関数が伸張指数 関数型になることが示され，その理論的解釈を巡 って多くの理論が提出された.

一方，ガラス形成物質の動的構造因子も波数 . 振動数の広い領域で調べられ，ボゾンピークや速 い緩和, 遅い緩和等の特徵が明らかにされた[11].

また，広角の散乱実験により，ノンガウシアン パラメーターが直接測定され, ガラス転移点近傍 のダイナミックスの知見が格段に増加した[12]. 特に, ガラス転移点近傍でガウシアン的なダイナ ミックスからのずれが大きくなることが示され ている.

\section{2. 将来への期待}

過冷却液体などの不規則系は, 空間的な構造の 摇らぎにその特徵がある。前節で述べたように， ガラス形成過程においては, CRR 程度の原子集団 
のダイナミックスが重要な役割を果たすものと 考えられる。全系の平均的な性質ではなく，局所 的なダイナミックスの情報が大切である. そのた めに，次のような実験ができたらと期待している. 一つは，局所的構造をナノマニピュレーション によってコントロールした系に対する中性子実 験である．前節で述べたような閉じこめられた系 について散乱実験などが可能になれば，得られる 知見は飛躍的増大するものと思われる. コロイド などでは，そのような実験が行われようとしてお り, 高分子や単純液体のガラス形成物質の中性子 散乱などにおいても同様の実験を期待している.

もう一つの可能性として期待できるのは，フー リエ変換のように空間全体についての平均では なく，空間の局所構造を反映した散乱データの解 析である．例えば，音響データの解析によく用い られているウェーブレットを用いた散乱データ の解析ができれば，局所的なダイナミックスの情 報が得られ, 中性子散乱実験の新しい地平が開か れるものと期待できる. 密度摇らぎに対する非線 形応答と合わせて, 理論と実験の協力の下に新た に発展することを期待したい.

\section{5.おおりに}

ガラス転移の研究は, 1980 年代, 1990 年代に, 実験, 理論, 計算機シミュレーションの発展から 隆盛を見た：ガラス転移は，非平衡系における転 移であり，自由エネルギーの最小から理解できる 平衡系の相転移と同一には論じられない.

モード結合理論的描像か，レプリカ描像かある いはトラップモデルの描像か, どの描像がガラス 転移の動的及び熱力学的特徵を統一的に説明で きるのか, あるいは全く別の描像が必要なのか, それが今問われている。中性子実験からこの問に 対する答を是非出せることを期待している.

1990 年頃のノンガウシアンパラメーターの異 常の理論的予言が，中性子実験の新しい解析を動 機づけた. 前節で述べた理論家の夢も近いうちに 必ず実現されることを信じている.

\section{謝辞}

本稿執筆に際し貴重なコメントを頂いた京都 大学化学研究所 金谷利治教授に感謝致します. 第 3 節の密度汎関数理論による研究は, 吉留崇, 吉森明両氏との共同研究による.この研究は, 文 部科学省科学研究費補助金（基盤研究 B) の補助 を得て行われたものである。
参考文献

[1] W. Götze, in "Freezing and the Glass Transition in Liquids" (edited by J. P. Hansen, Levesque and J. Zinn-Just), (North Holland 1989) p.287; W. Götze, J. Phys.: Condens. Matt. 11, A1 (1999).

[2] M. Mèzard and G. Parisi, J. Chem. Phys. 111, 1076 (1999).

[3] T. Odagaki, Phys. Rev. Lett. 75, 3701 (1995); T. Odagaki, Prog. Theor. Phys. Suppl. 126, 9 (1997).

[4] T. Odagaki and Y. Hiwatari, Phys. Rev. A41, 929 (1990).

[5] T. Tao, A. Yoshiomori and T. Odagaki, Phys. Rev. E64, 046112 (2001); T. Odagaki, T. Yoshidome, T. Tao, and A. Yoshimori, J. Chem. Phys. 117, 10151 (2002); T. Tao, T. Odagaki and A. Yoshimori, J. Chem. Phys. 122, 044505 (2005).

[6] U. Mohanty, G. Diezemann and J. T. Fourkas, J. Chem. Phys. 113, 3719 (2000);V. B. Kokshenev and P. D. Borges, J. Chem. Phys. 122, 114510 (2005).

[7] G. Adam and J. H. Gibbs, J. Chem. Phys. 43, 139 (1965).

[8] T. V. Ramakrishnan and M. Yussouff, Phys. Rev. B. 19, 2775 (1979).

[9] T. Yoshidome, A. Yoshimori and T. Odagaki, cond-mat/0508499 (2005); in preparation.

[10] F. Mezei, W. Knaak and B. Farrago, Phys. Rev. Lett. 58, 571 (1987).

[11] 金谷利治, 高分子 52, 773 (2003); 金谷利治, 梶慶輔, 固体物理 29, 303 (1994).

[12] T. Kanaya, U. Buchenau and S. Koizumi, Phys. Rev. B61, R6451 (2000); R. Zorn, Phys. Rev. B55, 6249 (1997). 